\title{
Title:
}

\section{Safety and Immunogenicity of SARS-CoV-2 S-2P Protein Vaccine MVC-COV1901 in People Living with HIV}

Running title: S-2P protein vaccine MVC-COV1901 for HIV patients

Authors

Shu-Hsing Cheng ${ }^{\mathrm{a}, \mathrm{b} \dagger}$, Chia En Lien ${ }^{\mathrm{c}, \mathrm{d} \dagger}$, Szu-Min Hsieh ${ }^{\mathrm{e}, \mathrm{f}}$, Chien-Yu Cheng ${ }^{\mathrm{a}, \mathrm{g}}$, Wang-Da Liu ${ }^{\mathrm{e}, \mathrm{h}}$, Ching-Lung Lo ${ }^{\mathrm{i}, \mathrm{j}}$, Wen-Chien Ko ${ }^{\mathrm{i}, \mathrm{j}}$, Yen-Hsu Chen ${ }^{\mathrm{k}, 1}$, Ching-Tai Huang $^{\mathrm{m}, \mathrm{n}}$, Hsiao-Ting Chang ${ }^{\mathrm{o}, \mathrm{p}}$, Shinn-Jang Hwang ${ }^{\mathrm{o}, \mathrm{p}}$, Ning-Chi Wang ${ }^{\mathrm{q}}$, Ming-Che Liu $^{\text {r,s }}$, Yu-Lin Lee ${ }^{\mathrm{t}, \mathrm{u}}$, I-Chen Tai ${ }^{\mathrm{c}}$, Josue Antonio Garcia Estrada ${ }^{\mathrm{c}}$, Tzou-Yien Lin ${ }^{\mathrm{n}, \mathrm{v}}$, Wen-Sen Lee ${ }^{\mathrm{w}, \mathrm{x}^{*}}$

\section{Affiliations}

${ }^{\mathrm{a} D e p a r t m e n t ~ o f ~ I n f e c t i o u s ~ D i s e a s e s, ~ T a o y u a n ~ G e n e r a l ~ H o s p i t a l, ~ M i n i s t r y ~ o f ~ H e a l t h ~}$ and Welfare, Taoyuan, Taiwan (S-H Cheng MD, C-Y Cheng MD)

${ }^{\mathrm{b}}$ School of Public Health, Taipei Medical University, Taipei, Taiwan (S-H Cheng MD)

${ }^{\mathrm{c}}$ Medigen Vaccine Biologics, Taipei, Taiwan (CE Lien MD, I-C Tai MD, JAG

Estrada)

${ }^{\mathrm{d}}$ Institute of Public Health, College of Medicine, National Yang Ming Chiao Tung University, Taipei, Taiwan (CE Lien MD)

e Department of Internal Medicine, Division of Infectious Diseases, National Taiwan University Hospital, Taipei, Taiwan (W-D Liu MD, S-M Hsieh MD)

${ }^{\mathrm{f}}$ College of Medicine, National Taiwan University, Taipei, Taiwan (S-M Hsieh MD)

${ }^{\mathrm{g}}$ School of Public Health, National Yang Ming Chiao Tung University, Taipei,

Taiwan (C-Y Cheng MD)

${ }^{\mathrm{h}}$ Department of Medicine, National Taiwan University Cancer Center, Taipei, Taiwan (W-D Liu MD)

${ }^{\mathrm{i}}$ Department of Internal Medicine, National Cheng Kung University Hospital, Tainan, Taiwan (C-L Lo MD, Prof W-C Ko MD), ${ }^{\mathrm{j}}$ Department of Medicine, College of Medicine, National Cheng Kung University, Tainan, Taiwan (C-L Lo MD, Prof W-C Ko)

${ }^{k}$ Department of Internal Medicine, Division of Infectious Diseases, Kaohsiung Medical University Hospital, Kaohsiung, Taiwan (Prof Y-H Chen MD), ${ }^{\text {IS }}$ chool of Medicine, Graduate Institute of Medicine, Sepsis Research Centre, Centre 
of Tropical Medicine and Infectious Diseases, Kaohsiung Medical University, Kaohsiung, Taiwan; (Prof Y-H Chen)

${ }^{\mathrm{m}}$ Department of Infectious Diseases, Chang Gung Memorial Hospital, Taoyuan, Taiwan (Prof C-T Huang)

${ }^{\mathrm{n}}$ College of Medicine, Chang Gung University, Taoyuan, Taiwan (Prof C-T Huang, Prof T-Y Lin)

${ }^{\circ}$ Department of Family Medicine, Taipei Veterans General Hospital (H-T Chang MD, Prof S-J Hwang MD)

${ }^{\mathrm{p} S c h o o l}$ of Medicine, National Yang Ming Chiao Tung University, Taipei, Taiwan (H-T Chang MD, Prof S-J Hwang MD);

${ }^{\mathrm{q}}$ Tri-Service General Hospital, Taipei, Taiwan (N-C Wang MD)

${ }^{\mathrm{r}}$ Clinical Research Centre, Taipei Medical University Hospital, Taipei, Taiwan (M-C Liu MD)

${ }^{\mathrm{s}}$ School of Dental Technology, College of Oral Medicine (M-C Liu MD)

${ }^{\mathrm{t}}$ Department of Internal Medicine, Changhua Christian Hospital, Changhua, Taiwan (Y-L Lee MD);

urogram in Medical Biotechnology, National Chung Hsing University, Taichung, Taiwan (Y-L Lee);

${ }^{v}$ Department of Paediatrics, Chang Gung Memorial Hospital, Taoyuan, Taiwan (Prof T-Y Lin)

${ }^{\mathrm{w}}$ Division of Infectious Disease, Department of Internal Medicine, Wan Fang Hospital, Taipei Medical University, Taipei, Taiwan (W-S Lee MD)

${ }^{\mathrm{x}}$ Department of Internal Medicine, School of Medicine, College of Medicine, Taipei Medical University, Taipei, Taiwan (W-S Lee MD)

*Corresponding author: Wen-Sen Lee, MD. Tel: 886-2-29307930. email: 89425@w.tmu.edu.tw. Address: No.111, Sec.3, Xinglong Rd., Wenshan Dist., Taipei City 116, Taiwan.

${ }^{\dagger}$ These authors contributed equally 


\section{Abstract}

\section{Objectives}

To provide data on the immune response to COVID-19 vaccines in people living with HIV (PWH), MVC-COV1901, a recombinant protein vaccine containing S-2P protein adjuvanted with CpG 1018 and aluminium hydroxide, was assessed.

\section{Methods}

A total of $57 \mathrm{PWH}$ of $\geq 20$ years of age who are on stable antiretroviral therapy and with $\mathrm{CD}^{+} \mathrm{T}$ cell $\geq 350$ cells $/ \mathrm{mm}^{3}$ and HIV viral load $<10^{3}$ copies $/ \mathrm{ml}$ were compared with 882 HIV-negative participants. Participants received 2 doses of MVC-COV1901 28 days apart. Safety and the immunogenicity were evaluated.

\section{Results}

No vaccine-related serious adverse events (SAEs) were recorded. Seroconversion rates (SCRs) of $100 \%$ and $99.8 \%$ were achieved in people living with HIV (PWH) and comparators, respectively, 28 days after second dose. The geometric mean titers (GMTs) (95\% confidence interval [CI]) against wild type SARS-CoV-2 virus were $136.62 \mathrm{IU} / \mathrm{mL}$ (WHO Standardized International Unit) (95\% CI 114.3-163.3) and 440.41 IU/mL (95\% CI 421.3-460.4), for PWH and control groups, respectively, after adjusting for sex, age, BMI category, and comorbidity, and the adjusted GMT ratio of comparator/PWH was 3.22 (95\% CI 2.6-4.1). A higher 
medRxiv preprint doi: https://doi.org/10.1101/2021.12.08.21267439; this version posted December 9, 2021. The copyright holder for this preprint (which was not certified by peer review) is the author/funder, who has granted medRxiv a license to display the preprint in perpetuity.

It is made available under a CC-BY 4.0 International license.

$\mathrm{CD} 4 / \mathrm{CD} 8$ ratio was associated with a higher GMT $(\mathrm{R}=0.27, \mathrm{p}=0.039)$.

\section{Conclusions}

MVC-COV1901 has shown robust safety but weaker immunogenicity responses

in PWH. As a result, a third dose or booster doses of MVC-COV1901 may be appropriate for PWH.

Keywords: COVID-19 vaccine; CpG 1018; S-2P protein; HIV; CD4/CD8 ratio 


\section{Introduction}

The Coronavirus Disease 2019 (COVID-19), caused by the novel coronavirus SARS-CoV-2, was first reported in Wuhan, Hubei Province, People's Republic of China (PRC) in late December 2019. The disease spread rapidly around the globe and was declared a pandemic by the WHO on March $11^{\text {th }}, 2020 .{ }^{1,2}$ As of Nov. 2021, nearly 260 million infections and over 5 million deaths had occurred worldwide. ${ }^{3}$ Unfortunately, the disease has the most severe impact on people with poor socioeconomic status, and that includes populations vulnerable to HIV. ${ }^{3,4}$

People who are living with HIV (PWH) are subject to many risk factors that predispose for severe COVID-19. These factors include high rates of smoking, drug use, comorbidities including cardiovascular diseases, diabetes mellitus, chronic renal diseases, chronic liver diseases, and lung diseases. ${ }^{5-8}$ Furthermore, many PWH are overweight or obese, which correlates with the widespread use of second generation integrase inhibitors ${ }^{9,10}$ and is an additional risk factor for severe COVID-19. ${ }^{11,12}$ Health disparities due to socioeconomic status and stigmatization may also hinder early diagnosis of SARS-CoV-2 infection and timely provision of healthcare. ${ }^{4}$ Several case series and meta-analysis also pointed towards the association between PWH and severe COVID-19 and higher mortality rate. The U.S. RedCap data showed that COVID-19 affects PWH that are predominantly of older age (mean 51.4 years), 
African-American (47.5\%), and having high rates of comorbidity (80\%), with $57.3 \%$

of hospitalization, $16.5 \%$ of ICU admission, and $9.4 \%$ of mortality. ${ }^{13}$ Data captured

from the ISARIC WHO CCP study showed that after adjusting for age, PWH have

47\% higher mortality rates (adjusted hazard ratio 1.47, and 95\% confidence interval

[CI] 1.04-2.25) in England. ${ }^{14}$ The astonishingly rapid spread of COVID-19 spurred the desperate need of COVID-19 vaccines for PWH.

MVC-COV1901 is a subunit vaccine based on the stabilized prefusion SARS-CoV-2 spike protein S-2P $(15 \mathrm{mcg})$ with furin cleavage site mutation and T4 fibritin for trimerization, and formulated in adjuvant composed of TLR9 agonist CpG 1018 and aluminium hydroxide. ${ }^{15-17}$ Previous phase 1 and 2 clinical trials have shown that the MVC-COV1901 vaccine was well tolerated and elicited robust immune responses. ${ }^{18,19}$ In this study, PWH and the matched HIV-negative subjects were compared for the safety and immunogenicity of MVC-COV1901.

\section{Materials and Methods}

\section{Study design and participants}

This is a substudy within a Phase 2, prospective, double-blinded and multi-centre study to evaluate the SARS-CoV-2 vaccine MVC-COV1901. PWH were on stable antiretroviral therapy with $\mathrm{CD}^{+} \mathrm{T}$ cell count greater than 350 cells $/ \mathrm{mm}^{3}$ and HIV viral load less than $10^{3}$ copies/ml. We compared PWH from a per-protocol 
immunogenicity subset of the main study with HIV-negative participants of the main study. Participant's ages ranged from 20-87 and all received two standard doses of 15 mcg MVC-COV1901, administered 28 days apart via IM injection.

Immediate adverse events (AEs), both solicited local and systemic, and unsolicited AEs and adverse events of special interest (AESIs) were recorded throughout the study period.

Immunogenicity was assessed by measuring GMTs and SCRs of neutralizing antibody. The detection and characterization of neutralizing antibodies were performed by central laboratories using validated pseudovirus and/or live virus neutralization assays. ${ }^{19}$ To measure neutralizing antibody titers, wildtype SARS-CoV-2, Taiwan CDC strain number 4 (hCoV-19/ Taiwan/4/2020; Global Initiative on Sharing All Influenza Data accession ID EPI_ISL_411927), was titrated to calculate the $50 \%$ tissue culture infective dose $\left(\mathrm{TCID}_{50}\right)$. Vero E6 cells were seeded in 96-well plates (at $1.2 \times 10 \square$ cells per well) and incubated. Starting from a 1:8 dilution, the serum samples were diluted two-fold eight times to a final dilution of 1:1024. Diluted serum samples were then mixed with an equal volume of $100 \mathrm{TCID}_{50}$ per $50 \mu \mathrm{L}$ of virus. After incubating the serum-virus mixture at $37^{\circ} \mathrm{C}$ for $1 \mathrm{~h}$, it was added to the wells containing Vero E6 cells. The cells were then incubated at $37^{\circ} \mathrm{C}$ in a 5\% $\mathrm{CO}_{2}$ incubator for $4-5$ days. The neutralizing titer $\left(\mathrm{NT}_{50}\right)$ was defined as the 
reciprocal of the highest dilution capable of inhibiting $50 \%$ of the cytopathic effect.

The $\mathrm{NT}_{50}$ results were derived from quadruplicates and calculated with the

Reed-Muench method. Neutralizing antibody titers were converted to the WHO

Standardized Unit, IU/mL. The conversion is based on the WHO validated NIBSC

reference panel.

Statistical analysis

For the statistical analyses, descriptive statistics were first obtained and used to present sociodemographic and other characteristics. SCRs and 95\% confidence interval (CI) were computed for individuals with at least fourfold increase from the baseline. Fisher's exact test was used to compare seroconversion between the HIV group and the main group. GMTs were estimated from neutralizing antibody titers measured at 28 days after the second dose of the study intervention. GMT ratios, computed as the ratio between the GMT of neutralizing antibodies in the HIV subgroup versus control group, were also estimated. To assess the magnitude of the difference in immune response between the two groups, an analysis of covariance (ANCOVA) model was used. The model included the log-transformed antibody titers at Day 57 as the dependent variable, group (HIV subgroup and main group) as an explanatory variable and adjusted for age, BMI, gender and comorbidity profile. The 
95\% CI for the adjusted neutralizing antibody titers of each vaccine group was obtained. Then adjusted GMT was back-transformed to the original scale. Adjusted GMT ratio of the two groups and corresponding 95\% CI were also estimated. Correlation between GMT and CD4/CD8 ratio, and GMT and absolute $\mathrm{CD}^{+}{ }^{\mathrm{T}}$ cell count were analyzed using Spearman's test. One-way ANOVA was applied for calculating the correlation between GMT and HIV classification stages. Lastly, using age and gender as covariates and a digit-based greedy and nearest neighbor approach with a 1:5 ratio, propensity score matching was employed for robust comparison between 2 groups.

\section{Results}

\section{Study Population}

In the main study, a total of 3854 participants were randomised to treatment groups. Among them, $58 \mathrm{PWH}$ were randomized to the MVC-COV1901 group (Figure 1). One PWH was excluded from the analytic sample due to lack of information on an outcome indicator (i.e. neutralizing antibody titer). There were 882 participants who were HIV-negative and aged 20 to 87 in a per-protocol immunogenicity subset from the main study.

The demographic characteristics of the $57 \mathrm{PWH}$ and the 882 comparators from the main study are summarized in Table 1 . The mean age of the HIV group and the 
main group were 38.6 (Interquartile range [IQR] 27-46) and 45.7 (IQR 31-63) years, respectively $(\mathrm{p}=0.0026) ; 94.7 \%$ and $57.3 \%$ were male, respectively $(\mathrm{p}<0.0001)$; $19.3 \%$ and $11.5 \%$ had $\mathrm{BMI}>=30 \mathrm{~kg} / \mathrm{m} 2$, respectively $(\mathrm{p}=0.087)$, and $10.5 \%$ and 19.4\% had comorbidities at baseline, respectively $(\mathrm{p}=0.116)$.

\section{Outcomes}

\section{$\underline{\text { Safety }}$}

Overall, the percentages of participants in each category (solicited adverse events, unsolicited adverse events, and other adverse events after vaccination) were comparable between the HIV group and the main group in all age groups (Table 2-1 \& 2-2). The percentages of participants that reported solicited local adverse events were 58.6\%, and $72.3 \%$ for PWH and main group, respectively. For solicited systemic adverse events, $63.8 \%$, and 53.8\%, for PWH and main group. In both PWH and HIV-negative participants, pain or tenderness at injection site was the most common reported local reaction (67.2\% and $71.2 \%$, respectively). This event was slightly less common among PWH than HIV-negative individuals. Among systemic reactions, malaise and headache were the most common reaction in both groups but were predominantly mild to moderate in intensity. 


\section{$\underline{\text { Immunogenicity }}$}

After 2 doses of study intervention, the wild type SARS-CoV-2 neutralizing GMT's (95\% CI) on Day 57 (i.e. 28 days after the $2^{\text {nd }}$ dose) in HIV group and main group were $143.48 \mathrm{IU} / \mathrm{mL}(95 \%$ CI $115.5-178.3)$ and $439.01 \mathrm{IU} / \mathrm{mL}$ (95\% CI 419.5-459.5), respectively (Table 3). The GMT ratio (95\% CI) of main/HIV was 3.06 (95\% CI 2.5-3.8). After adjusting for sex, age, BMI category, and comorbidity profile, the GMT's (95\% CI) against wild type SARS-CoV-2 virus were $136.62 \mathrm{IU} / \mathrm{mL}(95 \%$

CI 114.3-163.3) and 440.41 IU/mL (95\% CI 421.3-460.4), respectively, and the adjusted GMT ratio (95\% CI) of main/HIV was 3.22 (95\% CI 2.6-4.1).

The seroconversion rates on Day 57 based on the wild type SARS-CoV-2 GMT were $100 \%$ in PWH group, and $99.8 \%$ in the main group with only two participants in the group failing to seroconvert.

\section{Correlation of GMT and CD4/CD8 ratio}

CD4/CD8 ratio was positively associated with GMT $(\mathrm{R}=0.27, \mathrm{p}=0.039)$ (Figure 2). No correlations were found between GMTs and $\mathrm{CD}^{+} \mathrm{T}$ cell count $(\mathrm{p}=0.3)$, and GMT and HIV classification stages ( $\mathrm{p}=0.44)$ (Figure S1 and Table S1).

\section{Adjusted GMT ratios}

Propensity scoring was employed to enable precise ratio determination. A total of 
326 subjects in the main study were selected for matching with PWH (Figure S2 and

Table S2). The adjusted GMT ratio of matched main/HIV was 3.22 (95\% CI 2.6-4.1)

(Table S3).

\section{Discussion}

To our knowledge, this is the first study focusing on the safety and immunogenicity of recombinant S-2P protein vaccine against COVID-19 in PWH.

The interim analysis demonstrated that in PWH participants aged 20 years and older, two doses of MVC-COV1901 vaccine were safe and well-tolerated, but less immunogenic than in HIV-negative controls. By the time the report was written, all participants having been followed-up for up to six months after the second booster dose.

Previous research raised the possibility that the immune status of PWH negatively modulates the immune responses to COVID-19 vaccines. Specifically, PWH have diminished or less durable responses to hepatitis B and yellow fever vaccination $^{20-22}$ and people with low CD4 cell counts have diminished antibody titers to pneumococcus, influenza, diphtheria, tetanus, and poliomyelitis. ${ }^{23-25}$ Despite these observations, most trials for COVID-19 vaccines have not addressed the PWH subpopulation by subgroup analysis or comparison of PWH with HIV-negative control groups. ${ }^{30}$ These trials include the mRNA-1273 SARS-CoV-2 vaccine phase 3 clinical 
trial that recruited $179 \mathrm{PWH},{ }^{26}$ the mRNA COVID-19 vaccine phase 3 trial, BNT162b2, that recruited $121 \mathrm{PWH},{ }^{27}$ and the Ad26.COV2.S vaccine phase 3 trial where $2.8 \%$ of the trial population were $\mathrm{PWH}^{28,29}$ Some trials did address $\mathrm{PWH}$ : the $\mathrm{nCoV}-2$ (AZD1222) vaccine studied 54 PWH in the United Kingdom, and 103 PWH in South Africa as part of the large phase 2/3 clinical trials of the AstraZeneca COVID-19 vaccine. ${ }^{31,32}$ All of the participants were on antiretroviral therapy and had high $\mathrm{CD} 4^{+}$ T-cell counts (median 694 cells $/ \mathrm{mm}^{3}$ and 695 cells $/ \mathrm{mm}^{3}$, respectively), and exhibited the same strength of immune response and safety profile, compared to HIV-negative comparators. Similarly a small non-clinical research effort with BNT162b2 involving $12 \mathrm{PWH}$ and 17 healthy donors had demonstrated comparable immunological response. ${ }^{33}$ Finally, Levy et al have studied 143 PWH who received the Pfizer-BioNTech vaccine. ${ }^{34}$ These PWH had antiretroviral therapy and had CD4 ${ }^{+}$ T-cell counts of 700 (95\% CI 648-757) cells $/ \mathrm{mm}^{3}$ and $94 \%$ of them had undetectable HIV viral load (< 40 copies $/ \mathrm{ml})$. Antibodies in these PWH were not inferior to HIV-negative people (98\% vs. 99\%). In contrast, Spinelli M. et al compared $100 \mathrm{PWH}$ with 100 persons without HIV and found 2.4-fold greater odds in PWH for a nonresponse to pseudovirus by antisera after vaccination with mRNA vaccines. ${ }^{35}$ In addition, the phase 3 clinical trial of NVX-CoV2373 against B.1.351 in South Africa included $201 \mathrm{PWH}$ and the vaccine efficacy was 60\% among HIV-negative group 
versus $49.4 \%$ for $\mathrm{PWH}^{36}$ Weaker neutralization antibody responses to Spike protein were demonstrated in this study, but it remains an open question if vaccine efficacy was actually reduced because cellular immunity was not measured.

$\mathrm{CD}^{+} \mathrm{T}$ cells orchestrate the response to acute and chronic viral infections by coordinating the immune system. These cells activate B cells to generate efficient neutralisation antibodies, cytotoxic $\mathrm{CD}^{+} \mathrm{T}$ cells to kill infected cells, and multiple cells of the innate immune system, and non-immune cells. Thus, $\mathrm{CD} 4^{+} \mathrm{T}$ cells play a key role for the establishment of long-term cellular and humoral antigen specific immunity, which is the basis of life-long protection for many viral infections and vaccines. ${ }^{37,38}$ In addition, $\mathrm{CD} 4^{+}$and $\mathrm{CD}^{+} \mathrm{T}$ cells produce interferon-gamma (commonly referred to as a "type 1" immune response) which is believed to be protective for the host. ${ }^{39}$ It is therefore a legitimate concern that the immune response could be impeded in PWH with abnormal $\mathrm{T}$ cell counts as measured by depleted memory $\mathrm{T}$ cells and inversed $\mathrm{CD} 4^{+} / \mathrm{CD}^{+}$ratios that may be indicative of the response of exhausted cytotoxic T cells toward HIV, and persistent immune activation and inflammation even during stable ART. ${ }^{40-42}$ Nevertheless, generation of high-affinity neutralizing antibodies was a key endpoint in this vaccine study.

Notably, in the study with MVC-COV1901 presented here, CD4 ${ }^{+}$T cell counts did not significantly correlate with GMT in the vaccinated PWH while increasing 
CD4/CD8 ratios did correlate. The adjuvant of MCV-COV1901, CpG 1018 (a toll-like receptor 9 agonist), may explain this correlation because it binds to the DNA receptor on plasmacytoid dendritic cells, and enhances immunogenicity by stimulating $\mathrm{CD}^{+}$helper and $\mathrm{CD}^{+}$cytotoxic $\mathrm{T}$ cells. ${ }^{43,44}$ Consistent with these observations, an independent $\mathrm{HBV}$ vaccine study in $\mathrm{PWH}$ demonstrated that $\mathrm{CD} 4 / \mathrm{CD} 8$ ratios $>0.4$ were associated with a high rate $(86 \%)$ of $\mathrm{HBV}$ seroconversion. $^{45}$

Despite these indications that cellular immunity may be important for durable protective immunity, there are arguments that long-lived plasma cells may have the potential to produce antibodies for decades in the absence of re-encounter with antigen or specific T cells. ${ }^{46}$ Add to this the $100 \%$ of seroconversion in PWH with MVC-COV1901, and it is clear that the role of $\mathrm{T}$ cell memory in durable protective immunity against SARS-CoV-2 deserves further study.

Despite the insights generated by our study, some limitations to interpretation may exist. First, the sample size in the PWH group was relatively small. Furthermore, all PWH were on stable ART and had $\mathrm{CD} 4^{+} \mathrm{T}$ cell counts greater than 350 cells $/ \mathrm{mm}^{3}$ and HIV viral load less than 1000 copies/ml. Thus, extrapolation to people with HIV with lower CD4 counts, or without suppressed HIV viral loads is not suggested. Second, our study was initiated when SARS-CoV-2 was not endemic in Taiwan, and 
the low viral transmission rate made it difficult to ascertain the efficacy of the vaccine as an exploratory endpoint. Specifically, low levels of $1 \%$ of neutralizing antibody titer were detected both at baseline and on Day 57 in the placebo group, suggesting that COVID-19 was rare and natural infection had not boosted the neutralizing antibody titers. ${ }^{19}$ Third, the short duration of the follow-up period in this study did not allow for assessing the durability of immune responses after Day 57. Fourth, although Th1-skewed immune responses had been demonstrated in the phase I MVC-COV1901 study, ${ }^{18}$ the T-cell responses to the vaccine among PWH were not assessed in this study. Finally, neutralization activities for other SARS-COV2 strains such as Alpha, Beta, Delta, Gamma, and Omicron variants, were not tested and cross-reactivity against emerging Variant of Concerns remains unknown.

In conclusion, this report describes a good safety profile but weaker immunogenicity of MCV-COV1901 in PWH, especially in those PWH with low CD4/CD8 ratios. MCV-COV1901 has emergency authorization use in Taiwan as of July $2021,{ }^{19}$ and has since advanced to larger clinical trials, including a trial initiated by WHO $^{47}$ Additional information accumulates from these trials, but further studies are needed to see if PWH require distinct immunization strategies with improved immunogenicity, such as boosters or additional doses, ${ }^{48,49}$ heterologous 
revaccination, ${ }^{50}$ higher doses as with hepatitis $\mathrm{B},{ }^{51}$ or even a $\mathrm{PWH}$-specific platform for booster shots similar to that for influenza vaccine ${ }^{52}$.

\section{Contributors}

S-HC, CEL and W-SL conceived and designed the study. W-SL, C-YC, W-DL, C-HL, W-CK, Y-HC, H-TC, H-JH, C-TH, N-CW, M-CL, and Y-LL acquired and interpreted the data. CEL, I-CT, and JAGE analyzed the data. S-HC, W-SL, and CEL drafted and prepared the manuscript. CEL, and I-CT had full access to and verified all the data in the study and take responsibility for the integrity of the data and the accuracy of the data analysis. All authors reviewed and approved the final version of the manuscript. S-HC, CEL, W-SL, and T-YL had final responsibility for the decision to submit for publication.

\section{Declaration of interests}

CEL, JAGE and I-CT are employees of Medigen Vaccine Biologics (Taipei, Taiwan) and they received grants from Taiwan Centres for Disease Control, Ministry of Health and Welfare, during the conduct of the study. All other authors declare no competing interests.

\section{Data sharing}

Data sharing is not applicable to this Article, as it is an interim analysis of data from an ongoing study.

\section{Acknowledgments}

The study was funded by Medigen Vaccine Biologics (study sponsor), the Taiwan Centers for Disease Control and Ministry of Health and Welfare. The sponsor co-designed the trial and coordinated interactions with contract Clinical Research Organization (CRO) staff and regulatory authorities. The CRO operated trial operation to meet the standards of the International Council for Harmonisation of Technical Requirements for Pharmaceuticals for Human Use and good clinical practice guidelines. The IDMC oversaw the safety data and communicated recommendations to the sponsor. The interim analysis was done by the CRO. We 
thank Stanley Chang, and Charles Chen at Medigen Vaccine Biologics; the investigational staff at National Taiwan University Hospital, Taiwan Taipei Veterans General Hospital, Tri-Service General Hospital, Taipei Veterans General Hospital, Taipei Medical University Hospital, Taipei Municipal Wan Fang Hospital, Linkou Chang Gung Medical Hospital, Taoyuan General Hospital Ministry of Health and Welfare, China Medical University Hospital, Changhua Christian Hospital, National Cheng Kung University Hospital, and Kaohsiung Medical University Chung-Ho Memorial Hospital, for their dedication to this trial; the Clinipace Clinical Research team (Taipei, Taiwan), for their involvement in conducting the trial; Barney S Graham at the Vaccine Research Centre, US National Institute of Allergy and Infectious Diseases, for the development of S-2P pre-fusion protein; Robert Janssen at Dynavax Technologies for providing the CpG 1018 adjuvant and related important intellectual content; members at Protech Pharmaservices (Taipei, Taiwan) for conducting the spike-specific IgG ELISA assay; members at the Department of Laboratory Medicine, Linkou Chang Gung Memorial Hospital (Taoyuan, Taiwan), and members at Institute of Biomedical Sciences, Academia Sinica (Taipei, Taiwan) for conducting the neutralisation assay.

\section{Reference List}

(1) World Health Organization. WHO Director-General's opening remarks at the mission briefing on COVID-19-11 March 2020. World Health Organization. March 11, 2020. Available at. WHO 2020 March 11 Available from: URL: https://www.who.int/director-general/speeches/detail/who-director-general-s-o pening-remarks-at-the-media-briefing-on-covid-19---11-march-2020. Accessed June 5, 2021.

(2) Zhou P, Yang XL, Wang XG, et al. A pneumonia outbreak associated with a new coronavirus of probable bat origin. Nature 2020 Mar;579(7798):270-3.

(3) Done E, Du I, Garder L. COVID-19 Dashboard by the Centrefor Systems Science and Engineering (CSSE) at Johns Hopkins University (JHU). Available at: https://coronavirus.jhu.edu/map.html.Accessed Nov 27, 2021. John Hopkins University 2021 July 30Available from: URL: Available at https://coronavirus.jhu.edu/map.html. Accessed Nov/27/ 2021.

(4) Yancy CW. COVID-19 and African Americans. JAMA 2020 May 
19;323(19):1891-2.

(5) Mdodo R, Frazier EL, Dube SR, et al. Cigarette smoking prevalence among adults with HIV compared with the general adult population in the United States: cross-sectional surveys. Ann Intern Med 2015 Mar 3;162(5):335-44.

(6) Shiau S, Arpadi SM, Yin MT, Martins SS. Patterns of drug use and HIV infection among adults in a nationally representative sample. Addict Behav 2017 May;68:39-44.

(7) Hasse B, Ledergerber B, Furrer H, et al. Morbidity and aging in HIV-infected persons: the Swiss HIV cohort study. Clin Infect Dis 2011 Dec;53(11):1130-9.

(8) Wong C, Gange SJ, Moore RD, et al. Multimorbidity Among Persons Living with Human Immunodeficiency Virus in the United States. Clin Infect Dis 2018 Apr 3;66(8):1230-8.

(9) Eckard AR, McComsey GA. Weight gain and integrase inhibitors. Curr Opin Infect Dis 2020 Feb;33(1):10-9.

(10) Sax PE, Erlandson KM, Lake JE, et al. Weight Gain Following Initiation of Antiretroviral Therapy: Risk Factors in Randomized Comparative Clinical Trials. Clin Infect Dis 2020 Sep 12;71(6):1379-89.

(11) Liu B, Spokes P, He W, Kaldor J. High risk groups for severe COVID-19 in a whole of population cohort in Australia. BMC Infect Dis 2021 Jul 16;21(1):685.

(12) Kang IS, Kong KA. Body mass index and severity/fatality from coronavirus disease 2019: A nationwide epidemiological study in Korea. PLoS One 2021;16(6):e0253640.

(13) Dandachi D, Geiger G, Montgomery MW, et al. Characteristics, Comorbidities, and Outcomes in a Multicenter Registry of Patients with HIV and Coronavirus Disease-19. Clin Infect Dis 2020 Sep 9.

(14) Geretti AM, Stockdale AJ, Kelly SH, et al. Outcomes of COVID-19 related hospitalization among people with HIV in the ISARIC WHO Clinical Characterization Protocol (UK): a prospective observational study. Clin Infect Dis 2020 Oct 23.

(15) Wrapp D, Wang N, Corbett KS, et al. Cryo-EM structure of the 2019-nCoV 
spike in the prefusion conformation. Science 2020 Mar 13;367(6483):1260-3.

(16) Kuo TY, Lin MY, Coffman RL, et al. Development of CpG-adjuvanted stable prefusion SARS-CoV-2 spike antigen as a subunit vaccine against COVID-19. Sci Rep 2020 Nov 18;10(1):20085.

(17) Lien CE, Lin YJ, Chen C, et al. CpG-adjuvanted stable prefusion SARS-CoV-2 spike protein protected hamsters from SARS-CoV-2 challenge. Sci Rep 2021 Apr 22;11(1):8761.

(18) Hsieh SM, Liu WD, Huang YS, et al. Safety and immunogenicity of a Recombinant Stabilized Prefusion SARS-CoV-2 Spike Protein Vaccine (MVC-COV1901) Adjuvanted with CpG 1018 and Aluminum Hydroxide in healthy adults: A Phase 1, dose-escalation study. EClinicalMedicine 2021 Jun 26; 100989 .

(19) Hsieh SM, Liu MC, Chen YH, et al. Safety and immunogenicity of CpG 1018 and aluminium hydroxide-adjuvanted SARS-CoV-2 S-2P protein vaccine MVC-COV1901: interim results of a large-scale, double-blind, randomised, placebo-controlled phase 2 trial in Taiwan. Lancet Respir Med 2021 Oct 13.

(20) van den Berg R, van H, I, van AM. Non-responsiveness to hepatitis B vaccination in HIV seropositive patients; possible causes and solutions. AIDS Rev 2009 Jul;11(3):157-64.

(21) Avelino-Silva VI, Miyaji KT, Hunt PW, et al. CD4/CD8 Ratio and KT Ratio Predict Yellow Fever Vaccine Immunogenicity in HIV-Infected Patients. PLoS Negl Trop Dis 2016 Dec;10(12):e0005219.

(22) O'Bryan TA, Rini EA, Okulicz J, et al. HIV viraemia during hepatitis B vaccination shortens the duration of protective antibody levels. HIV Med 2015 Mar;16(3):161-7.

(23) Kroon FP, van Dissel JT, Labadie J, van Loon AM, van FR. Antibody response to diphtheria, tetanus, and poliomyelitis vaccines in relation to the number of $\mathrm{CD}^{+} \mathrm{T}$ lymphocytes in adults infected with human immunodeficiency virus. Clin Infect Dis 1995 Nov;21(5):1197-203.

(24) Kroon FP, van Dissel JT, de Jong JC, van FR. Antibody response to influenza, tetanus and pneumococcal vaccines in HIV-seropositive individuals in relation to the number of CD4 ${ }^{+}$lymphocytes. AIDS 1994 Apr;8(4):469-76. 
(25) Hung CC, Chang SY, Su CT, et al. A 5-year longitudinal follow-up study of serological responses to 23-valent pneumococcal polysaccharide vaccination among patients with HIV infection who received highly active antiretroviral therapy. HIV Med 2010 Jan;11(1):54-63.

(26) Baden LR, El Sahly HM, Essink B, et al. Efficacy and Safety of the mRNA-1273 SARS-CoV-2 Vaccine. N Engl J Med 2021 Feb 4;384(5):403-16.

(27) Polack FP, Thomas SJ, Kitchin N, et al. Safety and Efficacy of the BNT162b2 mRNA Covid-19 Vaccine. N Engl J Med 2020 Dec 31;383(27):2603-15.

(28) Janssen Biotech i. FDA Briefing Document Janssen Ad26.COV2.S Vaccine for the Prevention of COVID-19. 2021.

(29) Sadoff J, Gray G, Vandebosch A, et al. Safety and Efficacy of Single-Dose Ad26.COV2.S Vaccine against Covid-19. N Engl J Med 2021 Jun 10;384(23):2187-201.

(30) Peebody R. Have COVID-19 vaccines been tested in people with HIV? available https://www.aidsmap.com/about-hiv/have-covid-19-vaccines-been-tested-peop le-hiv (accessed 30/Jul/2021). 2021.

(31) Frater J, Ewer KJ, Ogbe A, et al. Safety and immunogenicity of the ChAdOx1 nCoV-19 (AZD1222) vaccine against SARS-CoV-2 in HIV infection: a single-arm substudy of a phase $2 / 3$ clinical trial. Lancet HIV 2021 Aug;8(8):e474-e485.

(32) Madhi SA, Koen AL, Izu A, et al. Safety and immunogenicity of the ChAdOx1 nCoV-19 (AZD1222) vaccine against SARS-CoV-2 in people living with and without HIV in South Africa: an interim analysis of a randomised, double-blind, placebo-controlled, phase 1B/2A trial. Lancet HIV 2021 Sep;8(9):e568-e580.

(33) Woldemeskel BA, Karaba AH, Garliss CC, et al. The BNT162b2 mRNA Vaccine Elicits Robust Humoral and Cellular Immune Responses in People Living with HIV. Clin Infect Dis 2021 Jul 22.

(34) Levy I, Wieder-Finesod A, Litchevsky V, et al. Immunogenicity and safety of the BNT162b2 mRNA Covid-19 vaccine in people living with HIV-1. Clin Microbiol Infect 2021 Aug 23. 
(35) Spinelli M. Lower SARS-CoV-2 IgG and pseudovirus neutralization titers post-mRNA vaccination among people living with HIV. 2021.

(36) Shinde V, Bhikha S, Hoosain Z, et al. Efficacy of NVX-CoV2373 Covid-19 Vaccine against the B.1.351 Variant. N Engl J Med 2021 May 20;384(20):1899-909.

(37) Kaech SM, Wherry EJ, Ahmed R. Effector and memory T-cell differentiation: implications for vaccine development. Nat Rev Immunol 2002 Apr;2(4):251-62.

(38) Peng X, Ouyang J, Isnard S, et al. Sharing CD4 ${ }^{+} \mathrm{T}$ Cell Loss: When COVID-19 and HIV Collide on Immune System. Front Immunol 2020; $11: 596631$.

(39) Chen Z, John WE. T cell responses in patients with COVID-19. Nat Rev Immunol 2020 Sep;20(9):529-36.

(40) Papagno L, Spina CA, Marchant A, et al. Immune activation and CD8 ${ }^{+}$T-cell differentiation towards senescence in HIV-1 infection. PLoS Biol 2004 Feb;2(2):E20.

(41) McCune JM. The dynamics of $\mathrm{CD}^{+}$T-cell depletion in HIV disease. Nature 2001 Apr 19;410(6831):974-9.

(42) Lindqvist M, van LJ, Soghoian DZ, et al. Expansion of HIV-specific T follicular helper cells in chronic HIV infection. J Clin Invest 2012 Sep;122(9):3271-80.

(43) Hornung V, Rothenfusser S, Britsch S, et al. Quantitative expression of toll-like receptor 1-10 mRNA in cellular subsets of human peripheral blood mononuclear cells and sensitivity to $\mathrm{CpG}$ oligodeoxynucleotides. J Immunol 2002 May 1;168(9):4531-7.

(44) Hyer R, McGuire DK, Xing B, Jackson S, Janssen R. Safety of a two-dose investigational hepatitis B vaccine, HBsAg-1018, using a toll-like receptor 9 agonist adjuvant in adults. Vaccine 2018 May 3;36(19):2604-11.

(45) Fuster F, Vargas JI, Jensen D, et al. CD4/CD8 ratio as a predictor of the response to $\mathrm{HBV}$ vaccination in HIV-positive patients: A prospective cohort study. Vaccine 2016 Apr 7;34(16):1889-95. 
(46) Hammarlund E, Thomas A, Amanna IJ, et al. Plasma cell survival in the absence of B cell memory. Nat Commun 2017 Nov 24;8(1):1781.

(47) World Health Orgnization. WHO Statement on Solidarity Trial Vaccines. 2021.

(48) Krause PR, Fleming TR, Peto R, et al. Considerations in boosting COVID-19 vaccine immune responses. Lancet 2021 Oct 9;398(10308):1377-80.

(49) Winthrop KL, Whitley RJ, Aletaha D. SARS-CoV-2 and the rheumatology patient: the last 12 months and a boost in the future. Ann Rheum Dis 2021 Oct;80(10):1249-51.

(50) Zhang J, He Q, An C, et al. Boosting with heterologous vaccines effectively improves protective immune responses of the inactivated SARS-CoV-2 vaccine. Emerg Microbes Infect 2021 Dec;10(1):1598-608.

(51) Cruciani M, Mengoli C, Serpelloni G, et al. Serologic response to hepatitis B vaccine with high dose and increasing number of injections in HIV infected adult patients. Vaccine 2009 Jan 1;27(1):17-22.

(52) Caldera F, Mercer M, Samson SI, Pitt JM, Hayney MS. Influenza vaccination in immunocompromised populations: Strategies to improve immunogenicity. Vaccine 2021 Mar 15;39 Suppl 1:A15-A23. 
medRxiv preprint doi: https://doi.org/10.1101/2021.12.08.21267439; this version posted December 9, 2021. The copyright holder for this preprint (which was not certified by peer review) is the author/funder, who has granted medRxiv a license to display the preprint in perpetuity.

It is made available under a CC-BY 4.0 International license.

Figure 1. Study design and the trial profile

Figure 2. Correlation analysis for CD4/CD8 ratio with post vaccination

neutralization antibody titers. $P$ value (i.e. 0.039 ) for the Spearman's test indicates a significant relationship at a $5 \%$ significance level. 
medRxiv preprint doi: https://doi.org/10.1101/2021.12.08.21267439; this version posted December 9, 2021. The copyright holder for this preprint (which was not certified by peer review) is the author/funder, who has granted medRxiv a license to display the preprint in perpetuity.

It is made available under a CC-BY 4.0 International license.

Table 1. Demographic characteristics of the participants

\begin{tabular}{|c|c|c|c|}
\hline Item\MVC lot & $\begin{array}{l}\text { MVC-COV1901 } \\
\text { (HIV positive) }\end{array}$ & $\begin{array}{l}\text { MVC-COV1901 } \\
\text { Main Study }\end{array}$ & p-value \\
\hline \multicolumn{4}{|l|}{$\square$ Age (years) } \\
\hline $\mathrm{N}$ (Missing) & $57(0)$ & $882(0)$ & \multirow{5}{*}{0.0026} \\
\hline Mean (SD) & $38.6(13.1)$ & $45.7(16.65)$ & \\
\hline Median (IQR) & $36(19.0)$ & $43.0(32.0)$ & \\
\hline $\mathrm{Q} 1 \sim \mathrm{Q} 3$ & $27.0 \sim 46.0$ & $31.0 \sim 63.0$ & \\
\hline Min Max & $23.0 \sim 72.0$ & $20.0 \sim 87.0$ & \\
\hline \multicolumn{4}{|l|}{$\square$ Gender } \\
\hline N (Missing) & $57(0)$ & $882(0)$ & \multirow{3}{*}{$<0.0001$} \\
\hline Male & $54(94.7 \%)$ & $505(57.3)$ & \\
\hline Female & $3(5.3 \%)$ & $377(42.7)$ & \\
\hline \multicolumn{4}{|l|}{$\square$ BMI $\left(\mathbf{k g} / \mathbf{m}^{2}\right)$} \\
\hline $\mathrm{N}$ (Missing) & $57(0)$ & $882(0)$ & \multirow{5}{*}{0.858} \\
\hline Mean (SD) & $25.3(4.9)$ & $24.9(4.1)$ & \\
\hline Median (IQR) & $24.45(6.2)$ & $24.41(5.25)$ & \\
\hline Q1 Q3 & $21.9 \sim 28.04$ & $22.04 \sim 27.3$ & \\
\hline $\operatorname{Min} \sim \operatorname{Max}$ & $18.7 \sim 39.2$ & $14.4 \sim 45.2$ & \\
\hline \multicolumn{4}{|l|}{$\square$ BMI group } \\
\hline $\mathrm{N}$ (Missing) & $57(0)$ & $882(0)$ & \multirow{3}{*}{0.076} \\
\hline$<30 \mathrm{~kg} / \mathrm{m}^{2}$ & $46(80.7 \%)$ & $781(88.6)$ & \\
\hline$>=30 \mathrm{~kg} / \mathrm{m}^{2}$ & $11(19.3 \%)$ & $101(11.5)$ & \\
\hline \multicolumn{4}{|c|}{$\square$ Comorbidity Category } \\
\hline $\mathrm{N}$ (Missing) & $57(0)$ & $882(0)$ & \multirow{3}{*}{0.116} \\
\hline Yes & $6(10.5 \%)$ & $171(19.4)$ & \\
\hline No & $51(89.5 \%)$ & $711(80.6)$ & \\
\hline
\end{tabular}

(1) Abbreviations: $N=$ number of subjects in PPI population; $S D=$ standard deviation; $Q 1=$ first quartile (25th percentile); $Q 3=$ third quartile (75th percentile); $I Q R=$ interquartile range;

BMI=Body Mass Index; HIV=Human Immunodeficiency Virus.

Table 2-1. Solicited adverse events after any dosing 
medRxiv preprint doi: https://doi.org/10.1101/2021.12.08.21267439; this version posted December 9, 2021. The copyright holder for this preprint (which was not certified by peer review) is the author/funder, who has granted medRxiv a license to display the preprint in perpetuity.

It is made available under a CC-BY 4.0 International license.

\begin{tabular}{|c|c|c|c|c|c|c|}
\hline & \multicolumn{2}{|c|}{ All, n (\%) } & \multicolumn{2}{|c|}{$\begin{array}{c}\geq 20 \text { to }<65 \text { years, } n \\
(\%)\end{array}$} & \multicolumn{2}{|c|}{$\geq 65$ years, $n(\%)$} \\
\hline & $\begin{array}{c}\text { MVC-COV190 } \\
1 \\
(\mathrm{~N}=\mathbf{3 2 9 5})\end{array}$ & $\begin{array}{c}\text { HIV } \\
(\mathrm{N}=\mathbf{5 8} \\
)\end{array}$ & $\begin{array}{c}\text { MVC-COV190 } \\
1 \\
(\mathrm{~N}=\mathbf{2 5 7 5})\end{array}$ & $\begin{array}{c}\text { HIV } \\
(\mathrm{N}=54 \\
)\end{array}$ & $\begin{array}{c}\text { MVC-COV190 } \\
1 \\
(\mathrm{~N}=\mathbf{7 2 0})\end{array}$ & $\begin{array}{c}\text { HIV } \\
(\mathrm{N}=4 \\
)\end{array}$ \\
\hline $\begin{array}{l}\text { Any Solicited Local } \\
\text { AEs }\end{array}$ & $2381(72.3)$ & $\begin{array}{c}39 \\
(58.6)\end{array}$ & $2030(78.8)$ & $\begin{array}{c}37 \\
(59.3)\end{array}$ & $351(48.8)$ & $2(50.0)$ \\
\hline Pain/Tenderness & $2346(71.2)$ & $39(67.2)$ & 2009 (78.0) & $37(68.5)$ & $337(46.8)$ & $\begin{array}{c}2 \\
(50.0)\end{array}$ \\
\hline Grade 1 & $2237(67.9)$ & $\begin{array}{c}37 \\
(63.8)\end{array}$ & $1907(74.1)$ & $\begin{array}{c}35 \\
(64.8)\end{array}$ & $330(45.8)$ & $\begin{array}{c}2 \\
(50.0)\end{array}$ \\
\hline Grade 2 & $97(2.9)$ & $2(34.4)$ & $91(3.5)$ & $2(3.7)$ & $6(0.8)$ & 0 \\
\hline Grade 3 & $12(0.4)$ & 0 & $11(0.4)$ & 0 & $1(0.1)$ & 0 \\
\hline $\begin{array}{l}\text { Induration/Swellin } \\
\mathrm{g}\end{array}$ & $347(10.5)$ & $\mathbf{1}(1.7)$ & $286(11.1)$ & $\mathbf{1}(1.9)$ & $61(8.5)$ & $\mathbf{0}$ \\
\hline Grade 1 & $303(9.2)$ & $\mathbf{1}(1.7)$ & $246(9.6)$ & $\mathbf{1}(1.9)$ & $57(7.9)$ & 0 \\
\hline Grade 2 & $42(1.3)$ & 0 & $38(1.5)$ & 0 & $4(0.6)$ & 0 \\
\hline Grade 3 & $2(0.1)$ & 0 & $2(0.1)$ & 0 & 0 & 0 \\
\hline Erythema/Redness & $161(4.9)$ & $\mathbf{0}$ & $138(5.4)$ & $\mathbf{0}$ & $23(3.2)$ & $\mathbf{0}$ \\
\hline Grade 1 & $155(4.7)$ & 0 & $132(5.1)$ & 0 & $23(3.2)$ & 0 \\
\hline Grade 2 & $6(0.2)$ & 0 & $6(0.2)$ & 0 & 0 & 0 \\
\hline $\begin{array}{l}\text { Any Solicited } \\
\text { Systemic AEs }\end{array}$ & $1774(53.8)$ & $\begin{array}{c}37 \\
(63.8)\end{array}$ & 1484 (57.6) & $\begin{array}{c}35 \\
(65.8)\end{array}$ & $290(40.3)$ & $\begin{array}{c}2 \\
(50.0)\end{array}$ \\
\hline Malaise/Fatigue & $1186(36.0)$ & $\begin{array}{c}25 \\
(43.1)\end{array}$ & $1036(40.2)$ & $\begin{array}{c}24 \\
(44.4)\end{array}$ & $150(20.8)$ & $\begin{array}{c}1 \\
(25.0)\end{array}$ \\
\hline Grade 1 & $961(29.2)$ & $\begin{array}{c}22 \\
(43.1)\end{array}$ & $831(32.3)$ & $\begin{array}{c}24 \\
(44.4)\end{array}$ & $130(18.1)$ & $\begin{array}{c}1 \\
(25.0)\end{array}$ \\
\hline Grade 2 & $203(6.2)$ & $3(5.2)$ & $185(7.2)$ & $2(3.7)$ & $18(2.5)$ & $\begin{array}{c}1 \\
(25.0)\end{array}$ \\
\hline 1 Grade 3 & $22(0.7)$ & 0 & $20(0.8)$ & 0 & $2(0.3)$ & 0 \\
\hline Myalgia & $908(27.6)$ & $\begin{array}{c}10 \\
(16.7)\end{array}$ & $757(29.4)$ & $\begin{array}{c}14 \\
(25.9)\end{array}$ & $151(21.0)$ & $\begin{array}{c}2 \\
(50.0)\end{array}$ \\
\hline Grade 1 & $764(23.2)$ & $9(16.7)$ & $629(24.4)$ & $7(13.0)$ & 135 (18.8) & 2 \\
\hline
\end{tabular}


medRxiv preprint doi: https://doi.org/10.1101/2021.12.08.21267439; this version posted December 9, 2021. The copyright holder for this preprint (which was not certified by peer review) is the author/funder, who has granted medRxiv a license to display the preprint in perpetuity.

It is made available under a CC-BY 4.0 International license.

\begin{tabular}{|c|c|c|c|c|c|c|}
\hline & \multicolumn{2}{|c|}{ All, n (\%) } & \multicolumn{2}{|c|}{$\begin{array}{c}\geq 20 \text { to }<65 \text { years, } n \\
(\%)\end{array}$} & \multicolumn{2}{|c|}{$\geq 65$ years, $n(\%)$} \\
\hline & $\begin{array}{c}\text { MVC-COV190 } \\
1 \\
(\mathrm{~N}=\mathbf{3 2 9 5})\end{array}$ & $\begin{array}{c}\text { HIV } \\
(\mathrm{N}=58 \\
)\end{array}$ & $\begin{array}{c}\text { MVC-COV190 } \\
1 \\
(\mathrm{~N}=\mathbf{2 5 7 5})\end{array}$ & $\begin{array}{c}\text { HIV } \\
(\mathrm{N}=54 \\
)\end{array}$ & $\begin{array}{c}\text { MVC-COV190 } \\
1 \\
(\mathrm{~N}=720)\end{array}$ & $\begin{array}{c}\text { HIV } \\
(\mathrm{N}=4 \\
)\end{array}$ \\
\hline & & & & & & $(50.0)$ \\
\hline Grade 2 & $126(3.8)$ & $1(1.7)$ & $112(4.3)$ & $1(1.9)$ & $14(1.9)$ & 0 \\
\hline Grade 3 & $18(0.5)$ & 0 & $16(0.6)$ & 0 & $2(0.3)$ & 0 \\
\hline Headache & $730(22.2)$ & $\begin{array}{c}13 \\
(22.4)\end{array}$ & $631(24.5)$ & $\begin{array}{c}12 \\
(22.2)\end{array}$ & 99 (13.8) & $\begin{array}{c}1 \\
(25.0)\end{array}$ \\
\hline Grade 1 & $630(19.1)$ & $\begin{array}{c}12 \\
(20.7)\end{array}$ & $537(20.9)$ & $\begin{array}{c}11 \\
(20.4)\end{array}$ & $93(12.9)$ & $\begin{array}{c}1 \\
(25.0)\end{array}$ \\
\hline Grade 2 & $93(2.8)$ & $1(1.7)$ & $87(3.4)$ & $1(1.9)$ & $6(0.8)$ & 0 \\
\hline Grade 3 & $7(0.2)$ & 0 & $7(0.3)$ & 0 & 0 & 0 \\
\hline Diarrhoea & $497(15.1)$ & $\begin{array}{c}14 \\
(24.1)\end{array}$ & $422(16.4)$ & $\begin{array}{c}14 \\
(25.9)\end{array}$ & $75(10.4)$ & $\mathbf{0}$ \\
\hline Grade 1 & $411(12.5)$ & $\begin{array}{c}12 \\
(20.7)\end{array}$ & $350(13.6)$ & $\begin{array}{c}12 \\
(22.2)\end{array}$ & $61(8.5)$ & 0 \\
\hline Grade 2 & $75(2.3)$ & $2(3.4)$ & $62(2.4)$ & $2(3.7)$ & $13(1.8)$ & 0 \\
\hline Grade 3 & $11(0.3)$ & 0 & $10(0.4)$ & 0 & $1(0.1)$ & 0 \\
\hline Nausea/Vomiting & $254(7.7)$ & $6(10.3)$ & $219(8.5)$ & $6(11.1)$ & 35 (4.9) & $\mathbf{0}$ \\
\hline Grade 1 & $226(6.9)$ & $6(10.3)$ & $192(7.5)$ & $6(11.1)$ & $34(4.7)$ & 0 \\
\hline Grade 2 & $26(0.8)$ & 0 & $25(1.0)$ & 0 & $1(0.1)$ & 0 \\
\hline Grade 3 & $2(0.1)$ & 0 & $2(0.1)$ & 0 & 0 & 0 \\
\hline Fever & $23(0.7)$ & 0 & $16(0.6)$ & 0 & $7(1.0)$ & 0 \\
\hline Grade 1 & $14(0.4)$ & 0 & $8(0.3)$ & 0 & $6(0.8)$ & 0 \\
\hline Grade 2 & $6(0.2)$ & 0 & $6(0.2)$ & 0 & 0 & 0 \\
\hline Grade 3 & $2(0.1)$ & 0 & $2(0.1)$ & 0 & 0 & 0 \\
\hline Grade 4 & $1(<0.1)$ & 0 & 0 & 0 & $1(<0.1)$ & 0 \\
\hline
\end{tabular}

Table 2-2. Summary of unsolicited adverse events and other adverse events 
medRxiv preprint doi: https://doi.org/10.1101/2021.12.08.21267439; this version posted December 9, 2021. The copyright holder for this preprint (which was not certified by peer review) is the author/funder, who has granted medRxiv a license to display the preprint in perpetuity.

It is made available under a CC-BY 4.0 International license.

\begin{tabular}{|c|c|c|c|c|c|c|}
\hline & \multicolumn{2}{|c|}{ All, $n(\%)$} & \multicolumn{2}{|c|}{$\geq 20$ to $<65$ years, $n(\%)$} & \multicolumn{2}{|c|}{$\geq 65$ years, $n(\%)$} \\
\hline & $\begin{array}{c}\text { MVC-COV19 } \\
01 \\
(\mathrm{~N}=3295)\end{array}$ & $\begin{array}{c}\text { HIV in } \\
\text { MVC-COV19 } \\
01 \\
(\mathrm{~N}=58)\end{array}$ & $\begin{array}{c}\text { MVC-COV19 } \\
01 \\
(\mathrm{~N}=2575)\end{array}$ & $\begin{array}{c}\text { HIV in } \\
\text { MVC-COV19 } \\
01 \\
(\mathrm{~N}=54)\end{array}$ & $\begin{array}{c}\text { MVC-COV19 } \\
01 \\
(\mathrm{~N}=720)\end{array}$ & $\begin{array}{c}\text { HIV in } \\
\text { MVC-COV19 } \\
01 \\
(\mathrm{~N}=4)\end{array}$ \\
\hline $\begin{array}{l}\text { Unsolicited } \\
\text { AEs }\end{array}$ & $932(28.3)$ & $17(29.3)$ & 767 (29.8) & $17(29.6)$ & 165 (22.9) & 0 \\
\hline $\begin{array}{l}\text { Related } \\
\text { unsolicited } \\
\text { AEs }\end{array}$ & $406(12.3)$ & $8(13.8)$ & $340(13.2)$ & $396(13.2)$ & $66(9.2)$ & 0 \\
\hline $\begin{array}{l}\text { Unsolicited } \\
\text { AEs } \\
\geq \text { Grade } 3\end{array}$ & $93(2.8)$ & $3(5.2)$ & $86(3.3)$ & $96(3.2)$ & $7(1.0)$ & 0 \\
\hline $\begin{array}{l}\text { Related } \\
\text { unsolicited } \\
\text { AEs } \\
\geq \text { Grade } 3\end{array}$ & $21(0.6)$ & 0 & $20(0.8)$ & $24(0.8)$ & $1(0.1)$ & 0 \\
\hline SAEs & $18(0.5)$ & $1(1.7)$ & $16(0.6)$ & $17(0.6)$ & $2(0.3)$ & 0 \\
\hline $\begin{array}{l}\text { Related } \\
\text { SAEs }\end{array}$ & 0 & 0 & 0 & 0 & 0 & 0 \\
\hline AESI & $1(<0.1)$ & 0 & 0 & 0 & $1(0.1)$ & 0 \\
\hline VAED & 0 & 0 & 0 & 0 & 0 & 0 \\
\hline $\begin{array}{l}\text { AEs leading } \\
\text { to study } \\
\text { intervention } \\
\text { discontinuati } \\
\text { on }\end{array}$ & $2(0.1)$ & 0 & 0 & $1(<0.1)$ & $2(0.3)$ & 0 \\
\hline $\begin{array}{l}\text { AEs leading } \\
\text { to study } \\
\text { withdrawal }\end{array}$ & $1(<0.1)$ & 0 & 0 & 0 & $1(0.1)$ & 0 \\
\hline Death & 0 & 0 & 0 & 0 & 0 & 0 \\
\hline
\end{tabular}

Abbreviations: $\mathrm{AE}=$ adverse event; $\mathrm{AESI}=$ adverse events of special interest $\mathrm{CI}=$ confidence interval; $\mathrm{N}=$ number of participants in the population; $\mathrm{n}=$ number of participants with events; $\mathrm{SAE}=$ serious adverse event $; \mathrm{VAED}=$ vaccine-associated enhanced disease 
Table 3. Comparison of wild type SARS-CoV-2 neutralizing antibody (Nab) in $\mathrm{IU} / \mathrm{mL}$

\begin{tabular}{|c|c|c|}
\hline Item\MVC lot & $\begin{array}{c}\text { MVC-COV1901 } \\
\text { HIV positive }(\mathbf{n}=57)\end{array}$ & $\begin{array}{c}\text { MVC-COV1901 } \\
\text { Main Study }(n=882)\end{array}$ \\
\hline $\mathrm{Nab}$ titer (GMT) in IU/mL & 143.48 & 439.01 \\
\hline $95 \% \mathrm{CI}$ of Nab titer & $115.5 \sim 178.3$ & $419.5 \sim 459.5$ \\
\hline \multicolumn{3}{|c|}{ Main/HIV } \\
\hline Nab titer Ratio & 3.06 & \\
\hline $95 \% \mathrm{CI}$ of $\mathrm{Nab}$ titer Ratio & $2.5 \sim 3.8$ & \\
\hline $\begin{array}{c}\text { Adjusted Nab titer (GMT) } \\
\text { in IU/mL }\end{array}$ & 136.62 & 440.41 \\
\hline $\begin{array}{c}95 \% \text { CI of Adjusted Nab } \\
\text { titer }\end{array}$ & $114.3 \sim 163.3$ & $421.3 \sim 460.4$ \\
\hline \multicolumn{3}{|c|}{ Main/HIV } \\
\hline Adjusted Nab titer Ratio & 3.22 & \\
\hline $\begin{array}{c}\text { 95\% CI of Adjusted Nab } \\
\text { titer Ratio }\end{array}$ & $2.6 \sim 4.1$ & \\
\hline
\end{tabular}




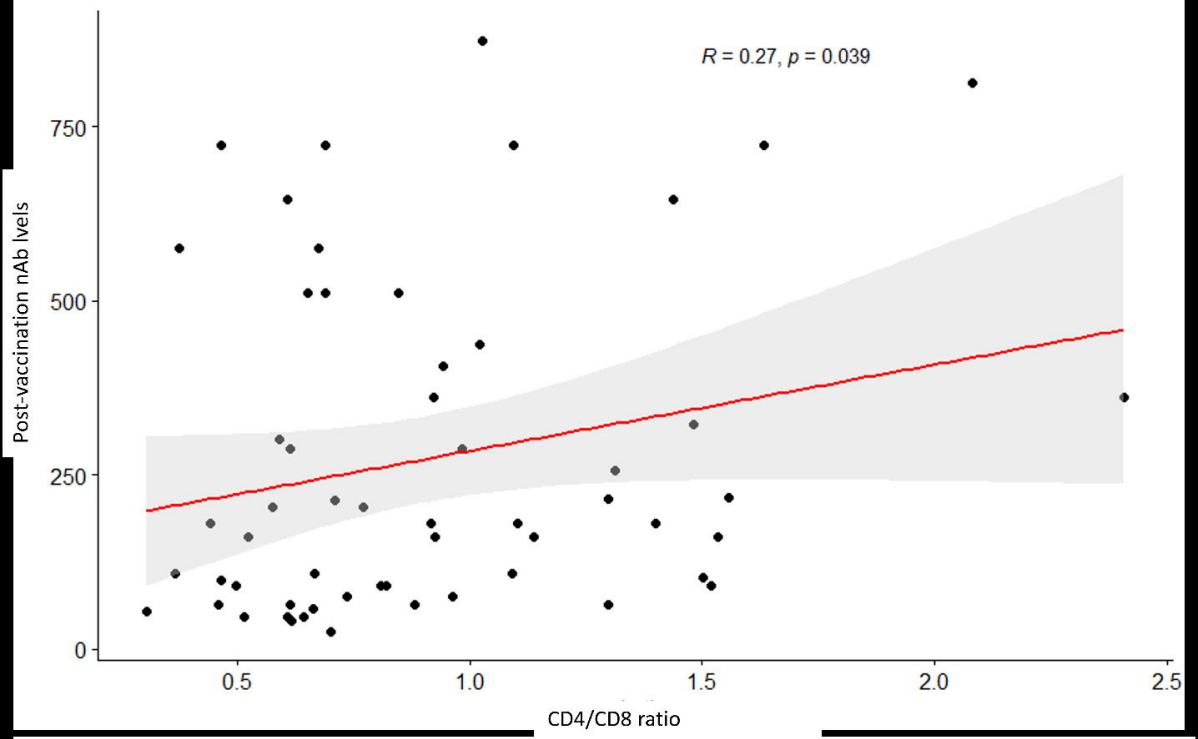

P-value (i.e., 0.039) for the Spearman's test indicate a significant relationship at a 5\% significance level. CD4/CD8 ratio is significantly correlated with post vaccination neutralizing antibody titers. The CD4/CD8 ratio is positively associated with Nab levels. 
$\mathbf{n}=\mathbf{5 5 6}$ excluded owing

to unmatched propensity scores
Participants matched through PSM, $n=326$ 